Mette Bundvad - Kasper Siegismund (eds.), Vision, Narrative, and Wisdom in the Aramaic Texts from Qumran. Essays from the Copenhagen Symposium, 14-15 August, 2017 (with the collaboration of Melissa Sayyad Bach Søren Holst - Jespers Høgenhaven) (Studies on the Texts of the Desert of Judah 131; Leiden - Boston, MA: Brill 2020)*. Pp. 289. €119. Hardcover. ISBN 978-90-04-41370-2

\title{
HENRYK DRAWNEL
}

\author{
The John Paul II Catholic University of Lublin \\ hdrawnel@kul.pl \\ ORCID: 0000-0003-4425-315X
}

The Aramaic Qumran manuscripts, although few and quite fragmentary, constitute an important part of all the texts found at Qumran and other places in the desert of Judah. Since some of them predate the foundation of the Essene community at Qumran, they bear witness to a period in the history of the Second Temple in Israel that until today is little known, mainly because of a lack of historical sources stemming from the third and beginning of the second century BCE. They comprise both pseudepigrapha of the Old Testament known from later, mostly Christian, tradition (e.g., 1 Enoch) as well as books found in the shorter, Hebrew canon (e.g., Daniel) and in the Septuagint version (Tobit). To the Aramaic lore retrieved from the Qumran caves belong the Targum to Leviticus and the Targum to Job, which bear witness to the earliest known evidence of translations of authoritative scriptures undertaken in post-exilic Judah. The discoveries in Wadi Murabba'at, Naḥal Hever and Naḥal Mishmar brought to light Aramaic legal documents dated mostly to the period of the Bar Kochba revolt.

The Aramaic manuscripts discovered mostly in the 1950s and 1960s attracted the attention of the scholarly world interested in the oldest attested pseudepigraphic and biblical text witnesses. Their discovery caused a considerable revision of the earlier theories concerning the date as well as the original language of composition of the earliest pseudepigrapha. One of the examples in case is 4Q208 that contains a lunar calculation similar to that found in the Ethiopic version of 1 Enoch 73:4-8 in a form more developed and more coherent than the versional evidence from a considerably later period. Additionally, since that Astronomical manuscript has palaeographically been dated to the end of the third or

* This review is an enlarged and reworked version published in Theologishe Literaturzeitung. 
the beginning of the second century $\mathrm{BCE}$, it became certain that the composition of the Astronomical Book as well as the beginning of Jewish apocalyptic literature had to be pushed back to at least the third century BCE.

The conference held at the Royal Dutch Academy of Sciences and Letters in August 2017 and organized by a team of Dutch scholars working at the University of Copenhagen took up the study of the Aramaic manuscripts from Qumran, literary works contained therein, their messages, historical contexts as well as a plethora of issues related with their social and historical settings. The volume under review contains papers presented and discussed during this conference and published in the Studies on the Texts of the Desert of Judah series. The organizers are to be complimented for setting up an international forum of discussion dedicated to the Aramaic texts from Qumran, a rather rare undertaking in the field of Qumran studies in recent decades.

The volume edited by Mette Bundvad and Kasper Siegismund contains twelve papers structured into three thematic groups. The authors of the first four articles discuss the concept of memory and expectations in the context of religious past and eschatological future as envisioned in individual Aramaic texts from Qumran. Andrew B. Perrin studies the Aramaic Pseudo-Danielic texts (4Q243-244; 4Q245) detecting scribal memories and innovations in shaping the figure of Daniel, known from earlier biblical and Near Eastern compositions, in them ("Remembering the Past, Cultivating a Character: Memory and the Formation of Daniel in the Aramaic Pseudo-Daniel Texts [4Q243-244; 4Q245]," pp. 6-30). Mika S. Pajunen attracts the attention of the reader to the transmission process of patriarchal figures in the Aramaic corpus from Qumran, focusing on Enoch, Noah, Abram as well as on Levi, Qahat and Amram ("Transmitting Patriarchal Voices in Aramaic: Claims of Authenticity and Reliability," pp. 31-51). The authors of the Qumran Aramaic compositions stemming from the late Second Temple period relied on the traditions found in Genesis to augment them with their own interpretations and with new revelatory material. The emphasis on the pre-Sinai events led to the inclusion of cosmological and universal perspectives of the universal union of humans and angels opposed by the forces of Belial into the theological mindset in which the covenant and revelation at Sinai, chronologically later, became relativized and subject to theological verification. While analyzing the fragmentary text of the New Jerusalem composition (4Q554, 4Q554a, 4Q555, 5Q15, 11Q18, 1Q32[?]), Hugo Antonissen reconstructs the architecture of the ideal city and compares banquet houses and their furnishing with the Graeco-Roman dining rooms, which serves for him as a starting point for the study of Greek banquet culture in comparison with Jewish pious banquet customs ("The Banquet Culture in New Jerusalem, An Aramaic Text from Qumran," pp. 52-77). Torleif Elgvin takes up a challenging task of searching for the traditio-historical background of the mysterious priestly figure in 4Q541 that 
he classifies as a Levi testament ("Trials and Universal Renewal-the Priestly Figure of the Levi Testament 4Q541," pp. 78-100). The opposition encountered by the eschatological priest together with the motifs of trials, suffering and atonement are drawn from Isaiah 50 and 53, his central role as a priestly leader depends on Ezekiel 40-48, while his redemptive function is related to Jer 30:18-24 and perhaps Zech 13.

The next four articles examine several topics concerning the Visions of Amram (4Q543-4Q546; 4Q547; 4Q548), an Aramaic composition in which Amram, Levi's grandson, plays the most prominent role. The first three articles deal with the role of Levi and Moses in Amram's life and the geographic descriptions of Egypt, Canaan and Philistea. The fourth article attempts to propose a new reconstruction of the fragmentary composition dedicated to Amram. Considering the Visions of Amram to have a testamentary form, Liora Goldman identifies Amram's son called "the angel of God" with Moses, the future leader of Israel ("Between Aaron and Moses in 4QVisions of Amram," pp. 101-118). Additionally, she argues that the special prominence ascribed to Aaron in the Visions subordinates the exodus of the whole nation from Egypt to the testament of the priestly line. Jesper Høgenhaven pays close attention to the geographical names and setting of the Visions of Amram discovering therein a sequence of temporal periods known from the Pentateuch: Patriarchs in Canaan - Israelites in Egypt, at Mt. Sinai, and finally in Canaan ("Geography in the Visions of Amram Texts [4Q543-547]," pp. 119-136). The visionary experience by Amram that takes place in Canaan makes from the father of Moses a successor of the patriarchs, while his travels (Egypt - Canaan - Sinai -Egypt) constitute an inversion of the background story that deals with the movement of the whole family/nation in and out of Egypt. Piecing together the original sequence of the Aramaic fragments of the Visions of Amram constitutes a challenging endeavor undertaken by Søren Holst ("Fragments and Forefathers: An Experiment with the Reconstruction of 4QVisions of Amram," pp. 137-152). Due to the overlaps found between fragments in 4Q543-4Q547, he transcribes the Aramaic text in the following order: 4Q545, cols. I-IV; 4Q544, col. I; 4Q543, cols. I-II, V; 4Q547, col. III. Since the verb נתן "to give" (4Q543 2 1-2) was interpreted by Robert Duke as a case of the 3 rd person singular suffix conjugation, Kasper Siegismund notes that there are no other instances of the root in the Qumran corpus that would attest to a similar verbal use ("4Q543 2 1-2 and the Verb 'To Give' in Qumran Aramaic," pp. 153-167). Since in Qumran Aramaic the verb נתן is attested in the prefix conjugation with the suppletive יהב used in the perfect, נתן Siegismund considers Duke's interpretation as unlikely, and parses the form as a 1 st person plural "we will give."

The last group of the four articles discusses the socio-historical context of the Qumran Aramaic texts, their relation to the New Testament and recent 
"discoveries" of some additional Qumran fragments turned out to be modern forgeries. Departing from available archaeological and historical data from the Persian and Hellenistic period in ancient Israel, Daniel A. Machiela reconstructs a hypothetical socio-historical scenario that could correspond to historical and literary data retrieved from most Aramaic texts found at Qumran ("The Compositional Setting and Implied Audience of Some Aramaic Texts from Qumran: A Working Hypothesis," pp. 168-202). The authors of these texts, often of a hortatory or didactic character, recruited from a small group of elite priests living in Jerusalem in Judea during the fourth to mid-second century BCE. In their compositions, they frequently recurred to antediluvian, patriarchal and priestly traditions so as to preserve and strengthen the observance of the ancestral (legal) tradition and faithfulness to the God of Israel, fend off intermarriage, but at the same time remain in dialogue with foreign cultures and powers. Being convinced that some parts of the material characteristic of the Gospel of Luke resonate with themes and motifs found in Qumran Aramaic texts, George J. Brooke compares the figure of the "son of God" and "son of the Most High" in 4Q246 with the application of the corresponding Greek expressions to Jesus in Luke 1:32-35 ("Aramaic Traditions from the Qumran Caves and the Palestinian Sources for Part of Luke's Special Material," pp. 203-220). He notes that Luke may have had access to the Palestinian tradition about the son of God whether in its Aramaic form (4Q246) or a Greek translation, and applied it to Jesus in a positive context, thus supplying his other sources on which he relied, that is Mark and Q source. The second point of contact with Aramaic traditions in the Luke's Gospel is the correlation of Enoch as the seventh (Luke 3:37; 1 En. 60:8; 93:3; Jub. 7:39; Jude 14) in Luke's genealogy (Luke 3:23-38) and Jesus as the seventy seventh (Luke 3:23). Read in the context of $1 \mathrm{En} .10: 12$ (binding of the Watchers for 70 generations), Luke's genealogy would indicate Jesus as the one who initiates the generation of the final judgment (Enoch being the seventh generation plus 70 generations of the expectation for the day of the great judgment). While this insight originally is drawn from Richard Bauckham's study (Jude and the Relatives of Jesus in the Early Church [Edinburgh: Clark] 1990), Brooke seems to positively accept Bauckham's conclusion, adding some notes on the position of Enoch and Levi in Luke's genealogy, which in the case of Levi might result from a prominent position of Levi as the founder of Levitical priesthood in the Aramaic priestly compositions of the Second Temple period. Finally, the author of the study draws the attention to the healing of the woman in Luke 13:10-17 and 1QapGen XX, 26-30, where Abraham expels the evil spirit from the household of the Egyptian king. In both narratives, the laying of the hands and healing are constitutive elements of the exorcism performed.

Melissa Sayyad Bach returns to 4Q246 to propose a collective understanding of the Aramaic syntagm "people of God" interpreted independently from the fig- 
ure of the "Son of God," a point that differentiates her approach from earlier studies of the text ("4Q246 and Collective Interpretation," pp. 221-241). She also reads the whole text as a narrative with simplistic and repetitive vocabulary. She identifies the decisive role of the people of God in causing the new age to begin and following Craig A. Evans proposes to read 4Q246 II, 4 as denoting the resurrection of the people of God. The article by Årstein Justnes discussing eight fake Dead Sea fragments closes the volume ("Fake Fragments, Flexible Provenances: Eight Aramaic 'Dead Sea Scrolls' from the 21st Century,” pp. 242-272). Being non-provenanced and undocumented, the fragments can be traced back to the Bethlehem antiquity dealer William Kando, son of Khalil Iskander Shahin. Four of them are part of the Schøyen collection, two belong to the South-Western Baptist Theological Seminary, and one is held at the Azusa Pacific University. Two fragments contain text taken from the book of Tobit, three contain a fragmentary text of the canonical book of Daniel, and other three are copies of 1 Enoch. Justnes's article is one in the series in which Qumran manuscript forgeries, which began to flood the antiquities market at the beginning of the 2000s, are exposed, and a certain naiveté of the buyers and publishers is stigmatized.

The twelve articles published in the volume discuss a wide array of topics often presenting new interpretive approaches and general pictures concerning texts, authors, and their social context, often painted with broad strokes and necessarily based on little information we now possess. The matter of fact is that, except for fragmentary compositions written in Aramaic, scholars of the Second Temple period lack comparative evidence concerning the social texture of the Jewish society, its most important institutions, such as the temple, priesthood, structures of power, sacrifices, education system, family life, and many other facets of everyday life in ancient Judaea. If not for the writings of Ezra, Hecataeus of Abdera, and Josephus Flavius, our knowledge about priesthood and its role in the society would be close to null. In other areas, such as education and learning centers, we are not so lucky.

Thus, modern scholars are necessarily destined to piece together available information with whatever they can retrieve from fragmentary Aramaic evidence. The overarching reconstruction of the socio-historical background and implied audience of all the Aramaic works from Qumran by Daniel A. Machiela ("The Compositional Setting and Implied Audience of Some Aramaic Texts from Qumran") is impressive. He paints with broad strokes the historical context of the Persian and Hellenistic Judea and stresses the need felt by the educated priestly class to bolster national identity as well as national pride in view of the lack of national independence and the surrounding cultural milieu with its syncretistic attitude to religion and intermarriage. One of the headings of the second part of his article (2.3) claims that "many of the Qumran Aramaic texts were written to a wide audience of Judeans and others identifying with Israel." This general 
statement may be true depending on the understanding of "many" as well as on our knowledge of literacy in Second Temple Judea. Thus, one wonders how large the "large audience" implied by the author of the article was.

Machiela argues that although the Astronomical Book and the so-called Aramaic Levi Document contain arithmetical calculations and mathematical sections, the narrative framework with apocalyptic features within which the latter are set preclude one from claiming that these two works were written exclusively for an internal, priestly study. He bolsters his case by listing some narrative parts of the Levi compositions, such as autobiographic tales, apocalyptic visions, and wisdom poem with its praise of international fame of a wisdom teacher. While all this is true, the contents of the two texts under discussion unequivocally point to a priestly audience interested in the origin of the Levitical priesthood and its (apocalyptic) future, audience that Levi unequivocally addresses in his wisdom poem. That not all the recipients of the simple arithmetical calculations in 4Q208-4Q209 frg. 22 were interested in that kind of literature is plainly attested by the Ethiopic Astronomical Book, where these calculations were simply excised. We do not know who and when decided to leave them out of the compilation of Enoch's apocalyptic material, but it is certain that whoever did it either did not understand its content or was not anymore interested in lunar calculations, preferring to concentrate on the length of the solar year and other calendrical matters. In other words, except for the information retrieved from these two texts and except for the number of their manuscripts in the Qumran caves, we do not have other means of assessing the size of their implied audiences that would cover larger strata of ancient Judean society, larger than around one hundred Yahad covenanters who read and copied them.

In some cases, comparative evidence from neighboring cultures appears to enlighten particular details otherwise unattested in other Jewish sources. This is, for example, the case of H. Antonissen's research ("The Banquet Culture in New Jerusalem, an Aramaic Text from Qumran") in which he notes that the white stone with which the new city of Jerusalem is paved is to be considered having a great value, just as in a Neo- or Late Babylonian Marduk hymn, in which the praise of Marduk's city contains the list of precious stones, white stone included. While the list of precious stones in New Jerusalem text is long, I am not sure whether it justifies Antonissen's conclusion "that the gigantic city in its totality is of a divine nature" (p. 57). While the comparison of the architecture of an insula in the Aramaic text of New Jerusalem with a peristylium in Alexandria shows certain similarities, it is not certain to which extent the "banquet rooms" and "couches" meant probably for reclining witness to the impact of the adoption of some features of the Greco-Roman banquets in the New Jerusalem composition. Eating and drinking in the context of sacrifices of Israel is mentioned in 11Q18 frg. 25 1-6 just as wine and oil in 11Q18 frg. 29 1-6. I do not understand 
why Antonissen places these two short fragments in the context of the sacred components of Greek banquets (pp. 63-64), where meat, wine and bread are always related to deities. Perhaps a more detailed reference to a sacrificial system attested in the Hebrew Bible would be in place here. The content of the next fragment, 11Q18 frg. 26, may relate to the Passover sacrifices and time for ritual purities (DJD 23, 345). Note that 11Q18 frg. 20//2Q24 frg. $49-16$ speaks about the shewbred consumed by the priests and the high priest, the liturgical context of the temple cult is therefore always present there.

Trying to substantiate his claim that the New Jerusalem text witnesses to a pious and respectful banquet culture, Antonissen discusses two aspects of the Greco-Roman banquet: entertainment in the form of "table talk" and "festive joy," drawing into discussion Ben Sira, the Letter of Aristeas, texts from Qumran caves, and Rabbinic literature (pp. 65-73). While concluding the point, he notes that the New Jerusalem composition mentions "the rooms of joy" only once in a fragmentary context (11Q18 frg. 18 5-6). Instead of discussing the expression within the context of the whole Aramaic composition, Antonissen refers to his notes in paragraphs 3 and 5 and concludes that 'the rooms of joy' are best understood in the context of the sacred nature of the Greco-Roman banquet, "the component of the meal that corresponds to entertainment in the form of 'table talk' in the Greco-Roman tradition, and 'festive joy." I wonder why Antonissen does not refer to the comment on the Aramaic expression in DJD 23, 334 that points to its use in Hatra and defines it as a part of the temple in that city, located probably on the first floor. Although its function at Hatra is unknown, Milik claims that it indicates a room used for communal meals. More research based on epigraphic evidence and temple structure at Hatra would be in place in further research on this Aramaic expression.

As one of the goals of her research, Goldman ("Between Aaron and Moses in 4QVisions of Amram") proposes to find the solution to the question "what is the main theme of the composition - the Levitical line and the establishment of the high priesthood or the national narrative of the exodus." From my point of view there is neither discrepancy nor mutual exclusion between these two topics. Since the biography of Amram related to biblical account necessarily leads to the exodus experience, the inclusion of sparse allusions to the exodus (4Q547 frg. 93-5) does not come as a surprise. It is a matter of contention to which extent the "copper altar" in 4Q547 frg. 95 denotes the altar made of acacia wood overlaid with copper/bronze in Exod 27:2. 11Q19 III, 14-16 speaks about a holocaust altar made of bronze. The syntagm "altar of bronze" in $2 \mathrm{Chr} 4: 1$ formally and semantically corresponds 4Q547 frg. 95.

Goldman concludes by stating that the special prominence given to Aaron leads to the interpretation of the biblical text that subordinates the exodus of Israel from Egypt to the testament of the priestly line (p. 117). It seems to me 
that the exodus understood as an event cannot be subordinated to a document, whether of priestly origin or not; rather, the text in 4Q547 frg. 9 speaks about the establishment of the priestly line in the context that oversteps the role of Aaron in Exodus and Leviticus: according to Amram's vision, Aaron (or his son?) will be exalted as a priest from among all the sons of the world/eternity (1. 9). The universal character of this priesthood exceeds the national role of Aaron and his descendants in the Pentateuch.

The symposium volume that focuses on the Aramaic texts from Qumran is a welcome addition to the burgeoning field of Qumran and Aramaic studies. From the overarching socio-cultural syntheses to a detailed analysis of single texts, it contributes to the field with new methodological approaches and adds a great number of fresh insights and analyses to what we already know about Jewish Aramaic literature of the late Second Temple period and its religious, cultural and theological impact on Jewish religion and nascent Christianity. It is to be hoped that Professor Høgenhaven's research team in cooperation with scholars from other countries will produce subsequent studies concerning Qumran Aramaic literature, the Visions of Amram, and priestly scribal literature in general. 